DOI: https://doi.org/10.24867/15FA09Bugarski

\title{
ENTERIJER STAMBENE JEDINICE - ANALIZA UTICAJA TEHNOLOGIJE NA DIZAJN
}

\section{INTERIOR OF A RESIDENTIAL UNIT - ANALYSIS OF THE IMPACT OF TECHNOLOGY ON DESIGN}

\author{
Aleksa Bugarski, Fakultet tehničkih nauka, Novi Sad
}

\begin{abstract}
Oblast - ARHITEKTURA - DIZAJN ENTERIJERA
Kratak sadržaj - Predmet ovog rada jeste uticaj odnosa tehnologije $i$ dizajna na korisnika ali $i$ na samog dizajnera odn. arhitektu. Analiza istorije industrijskog dizajna i enterijera, pokazuje kako je razvoj tehnologije donosio sa sobom nove norme ljudskog ponašanja $i$ drugačije poimanje prostora. Istraživanjem društvenih mreža i medija, kao novih prostora koji sve više okupiraju ljudsku pažnju, postaviće znak pitanja na ulogu arhitekte danas. Tehnologija i mediji danas stvaraju nove paterne ljudskog ponašanja koji su relativno novi pa ne mogu u potpunosti da se utvrde sve dobre i loše njihove strane.
\end{abstract}

Ključne reči: Arhitektura, enterijer, mediji, konzumerizam, tehnologija

Abstract - The subject of this thesis is the impact of the relationship between technology and design on the user but also on the designer. The analysis of the history of industrial design and interior shows how the development of technology brought with it new norms of human behavior and a different understanding of space. By exploring social networks and media, as new spaces that increasingly occupy human attention, it will question the role of the architect today. Technology and the media today are creating new patterns of human behavior that are relatively new so all the good and bad sides of them cannot be fully established.

Keywords: Architecture, interior design, mass-media, consumerism, tehcnology

\section{UVOD}

Stanja u društvu, nekadašnja i sadašnja kao i mogući pravci u kom se društvo kreće može se sagledavati kroz prizmu arhitekture, kao nauke koja se bavi ne samo prostorom već i odnosom čoveka sa njim. Ako arhitekturu i prostor posmatramo kroz dvojnost "spoljašnjosti i unutrašnjosti” - dva elementa jednako važna a envelopu, omot, okvir (uslovno rečeno fasadu) kao njihovu razliku, shvatamo da nijedan od tih elemenata ne možemo da analizamo odvojeno i bez da razumemo njihov uzajamni odnos. Ako razmatramo problematiku enterijera jasno je da njega ne čini sam prostor već i način na koji se taj prostor koristi, ko ga koristi, koji su to elementi koji ga sačinjavaju, dobra-stvari koje njegov korisnik korsti i odnos korisnika sa tim dobarima.

\section{NAPOMENA:}

Ovaj rad proistekao je iz master rada čiji mentor je bila dr Ivana Miškeljin, red. prof.
Cilj ovog rada jeste da prikaže uticaj odnosa tehnologije i dizajna na korisnika ali i na samog dizajnera odn. arhitektu. Analiza istorije industrijskog dizajna i enterijera, počev od Industrijske revolucije pa do danas, istaćiće kako je razvoj tehnologije donosio sa sobom nove norme ljudskog ponašanja kao i drugačije poimanje prostora.

Tehnologija i mediji danas stvaraju nove paterne ljudskog ponašanja koji su relativno novi pa ne mogu u potpunosti da se utvrde sve dobre i loše njihove strane. Da bi smo uvideli kako je tehnološki napredak kontinuirano uticao na društvo i njegov odnos prema prostoru kroz dizajn čime je menjao ne samo način već i kvalitet života, moramo se osvrnuti i na činioce tog društva i na sam prostor.

Iz tog razloga, kroz ovaj rad, sagledaćemo kako to čovek koristi prostor, kakve odnose stvara čovek sa elementima koji ga sačinjavaju, odnosno, psihološki aspekt odnosa čovek-prostor.

\section{ANALIZA UTICAJA TEHNOLOGIJE NA DIZAJN}

Primarni cilj arhitekture, tj. njena najvažnija funkcija jeste obezbeđivanje sigurnog i postojanog skloništa za čoveka od sveta koji ga okružuje. Kako je čovek kroz istoriju sve više savladavao i razumevao zakone fizike koji oblikuju prirodu i koristio ih prvo za izgradnju skloništa a potom i za neke druge egzistencijalne potrebe, došao je do tačke $u$ kojoj je to sklonište neupitna stvar i po pitanju sigunosti, postajnosti ali i u poslednja dva veka i po pitanju udobnosti.

Egzistencijalna udobnost dovela je do napretka u dužini životnog veka kao i do sve veće ljudske populacije. Razvijanjem tehnologije došlo je do diversifikacije struka i umnožavanja ljudskih potreba, ili onoga što se njima čini kao neophodnim i čini se da jedno sasvim opravdava drugo.

Arhitektonska struka danas prepoznaje više podstruka i daje mogućnost specijalizacije na različitim poljima: projektovanje, dizajn enterijera, industrijski dizajn, arhitektonska fotografija, 3D prezentacija itd. za razliku od arhitekte npr. 16. veka koji se uglavnom bavio konstrukcijom i oblikovanjem prostora.

Zadovoljavanje potreba velikog broja stanovništva kao i sama potreba za napredovanjem dovela je do prevelike eksploatacije planete Zemlje i njenih resursa, izazvavši ogromne klimatske promene. 
Jedan od gorućih problema u urbanim sredinama je zagađenost vazduha $i$ čini se da arhitekte ne vide potrebu za menjanjem mejnstrim narativa struke. Romantično zagledani jednim okom u neka davna vremena a drugim u nove ideale stvorene rukom današnjih Starchitects-a ne uviđaju potrebu za multidisciplinarnosti radi spasa ne samo planete već i same arhitektonske struke.

Međutim, optimizam pruža pojava nekoliko arhitektonskih praksi koje su se prilagodile tehnološkom narativu. Londoski studio EcoLogic Studio čine dvoje italijanskih arhitektata: Klaudija Paskvero i Marko Poleto. Studio je osnovan 2005. godine i specijalizovao se za biotehnologiju u arhitekturi. Teza Poleta o Urbanojsferi tvrdi da je povećana prostorna integracija ne-ljudskih sistema $u$ arhitekturi ključna za razvoj viših oblika urbane ekološke inteligencije.

Njihov projekat nazvan Urbana zavesa (Urban Curtain) ima za cilj da ubrza rešenje globalnih klimatskih promena hvatanjem $\mathrm{CO} 2 \mathrm{iz}$ atmosfere i skladištenjem približno jedan kilogram $\mathrm{CO} 2$ dnevno, što je ekvivalentno postojanjem 20 velikih stabala. Svaki modul funkcioniše kao fotobioreaktor, odnosno, kao digitalno dizajniran i prilagođen bioplastični kontejner koji koristi dnevnu svetlost za hranjenje živih kultura mikroalgi i oslobađa luminiscentne nijanse noću.

Photo.synth.etica funkcioniše tako što se nefiltriran gradski vazduh uvodi u dno fasade i počinje prirodno da putuje kroz mehuriće vazduha koji se izdižu kroz bioplastiku. Tada dolazi u kontakt sa proždrljivim mikroorganizmima koji hvataju i skladište molekule CO2 i zagađivače vazduha u algama i pretvaraju ih u biomasu. Ovo se može sakupljati i koristiti u proizvodnji bioplastične sirovine koja čini glavni građevinski materijal fotobioreaktora.

Ceo proces se završava kada se sveže fotosintetizovani kiseonik oslobodi na vrhu fasade i u urbanu mikroklimu [1].

Fokus na arhitektonskim pokretima 19. i 20. veka poslužiće za stvaranje jasnije slike o tome koji su faktori i sile utilcali na njihove nastanke, njihovu filozofiju i na njihove finalne produkte. Samu ovu sliku je potrebno uokviriti, postaviti u svojevrsni ram koji se sastoji od istorijskog konteksta koji objašnjava društveno-političku situaciju u kojoj nastaje velika transformacija u konzumersko društvo.

Istraživanjem društvenih mreža i medija, kao novih prostora koji sve više okupiraju ljudsku pažnju, a ne prepoznaju enterijer i eksterijer u svom arhetipskom značenju, postaviće znak pitanja na ulogu arhitekte danas. Dugo je tokom istorije razvoj tehnologije bio propraćen i lako pojmljiv arhitektonskoj struci ali se u 20. veku to drastično promenilo. Novo kapitalističko društvo i način proizvodnje donelo je sa sobom prazninu i osećaj neispunjenosti kod čoveka.

Psihoanaliza je našla vezu između pokušaja popunjavanja te praznine i kolekcionarskog fetiša. Upravo serijska proizvodnja omogućava konstantni osećaj ispunjenja sakupljanjem i popunjavanjem određenih kolekcija.

Veliku ulogu u proizvodnji igraju marketing timovi iza kojih stoje ozbiljne psihološke analize čovekovog ponašanja. Zadatak je da se naprave serije objekata koje će dalje stvoriti, prema Bodrijardu, serijske motivacije.
Napraviti objekat koji je nepotpun i koji nema značenje bez kupovine drugog objekta. Neograničenost $u$ konzumiranju proizvoda dolazi iz potrebe davanja smisla životu pa se stvari moraju i nedogled multiplicirati kako bi stvorile realnost koja je odsutna [2].

$\mathrm{Na}$ kraju kao finalni produkt ovih analiza, urađena su dva enterijera identične stambene jedinice, pojednostavljenih funkcija kako bi sam narativ došao do izražaja. Prvo rešenje predstavlja optimističan scenario u kom arhitektonska struka daje na značaju novim ekotehnologijama, okreće se više pojedincu i osveštava njegovo psihofizičko stanje.

Ovo enterijersko rešenje stambene jedinice sa optimističkim scenarijom predstavlja multidiscilpinarni pristup arhitekturi. Prihvatanje problematike klimatskih promena kao i konzumerizma kao problem koji dolazi kako iz društva tako i iz dubine same individue $\mathrm{i}$ njenog ne razumevanja sebe.

Sam projekat je nazvan „Egzistencijalna jedinica grad(ijent)“ sa naglaskom na gradijent kao simbol razumevanja dve različite strane i priznavanje postojanja nečeg drugog i suprotnog.

Drugi, mračniji scenario je zadržao arhitektonski konzervativni narativ iz čega je proizišao enterijer stambenog prostora koji u svom minimalizmu i u svojoj jednostavnosti predstavlja arhetipsku pećinu sa "oslikanim" zidovima poput onih u Altemiri. Istina se kao i u Platonovoj pećini nalazi izvan nje ali senke stvarnosti sačinjene od piksela trepere po zidovima ljudskog uma, sprečavajući ga da živi stvarnost i na kraju svesno bira simulaciju iskazivajući time pripadnost ostatku čovečanstva.

Ovaj projekat je propraćen i nazvan po kratkom scenariju „Pikselizirani enterijer ljudskog uma“ koji predstavlja kombinaciju literalne i slikovne prezentacije arhitekture.

\section{ZAKLJUČAK}

Brzina kojom se nižu tehnološke inovacije i njihov eksponencijalni rast nedostižni su razvoju ljudske svesti i ljudskog duha, a arhitektura kao nauka koja se bavi prostorom i čovekovim doživljajem tog prostora, sada se nalazi u sličnom problemu. Analizama u ovom radu pokazalo se da se čovek u predindustrijskom dobu indetifikovao najčešće svojim mestom u prostoru a nakon Industrijske revolucije, pojave kapitalizma i njegovih atributa - masovnosti i serijske proizvodnje, čovek počinje da se indetifikuje preko objekata koje konzumira. Daljim razvijanjem industrije i sve većim ulaganjem marketinških agencija u psihološka ispitivanja potrošačkog društva dolazi do akselerizacije konzumerizma i ne samo indetifikovanja preko objekata već i preko znaka (brenda) koji taj objekat reprezentuje.

Pa tako, počev od odeće koju nosimo, hranu koju jedemo, mesta koja posećujemo i na kraju način na koji projektujemo prostor i uređujemo ga predstavljaju način na koji se mi predstavljamo svetu i kako bi mi voleli da na nas ostali vide.

To stvara određeni raskorak sa realnošću i po francuskom filozofu Bodrijaru - Hiperrealnost. Pojavom interneta i društvenih mreža čovek sve više vremena provodi $u$ njihovim novim ,prostorima“. Iako je fizički pristutan $u$ 
realnom svetu, korisnik prostora svojom pažnjom okupira nova mesta. Novonastali multiprostori se preklapaju i sam korisnik gubi dodir sa realnošću i onim šta se oko njega događa. Pa čak i kad dopre do svesti i do toga šta se stvarno dešava, počev od globalnih problema do svakodnevnice čovek iznova bira beg i u digitalne prostore i delom se unutar njih bavi problemima.

Dodatnu dimenziju daju spektakl i hiperprodukcija kojom je čovek stalno izložen i sa kojom pokušava da bude u toku. Arhitektura je previše spora i troma i ne može da se prilagodi hiperprodukciji i potrebama korisnika zbog čega oni više provede vremena u multiprostoru u kojima se stvari odvijaju mnogo brže. Rasipanjem pažnje i energije na više prostora istovremeno otežava ljudima da prave promene i da se više bave realnim svetom.

Kako su uvek velike društvene promene i tehnološke inovacije donosile nova pitanja o slobodama, pravima, moralu i dužnosti, tako je i nova era interneta, mas-medija i mas-konzumerizma postavila nove granice ljudske svesti (ili je ako ništa drugo, stare delimično izbrisala).

Čini se da današnja arhitektura, koja se zbog svoje materijalizacije zasniva na dugotrajnosti i čvrstoći neće u potpunosti odgovarati korisniku u budućnosti. Fizički zidovi neće biti neophodni, razvoj tehnologije možda omogući da sam korisnik kreira prostor i da ga menja a urbani prostor možda dobije novu funkciju ili povrati staru oubličenu novim tehnologijama.

Ako se arhitektura konzumira kao ceo doživljaj prostora, ne samo fizički već ima i svoj psihološki moment, arhitekte bi trebali da budu $\mathrm{u}$ toku sa novim civilizacijskim narativom, da njihova multidisciplinarnost bude refleksija tih multiprostora. Psihologija, filozofija i znanja programskih jezika i način na koji najnovija tehnološka dostignuća utiču sociološki narativ neophodni su u današnje vreme.

Iz analiza tehnološkog napretka i njegovog uticaja na društvo uočava se, paralelno sa tehnološkim napretkom promena načina na koji se čovek identifikuje. U predindustrijskom svetu on je za to koristio prostor tako što je mesto koje je zauzimao npr. u centralnom holu tradicionalne britanske seoske kuće. Nakon industrijske revolucije i sve pristupačnijom robom širim masama, čovek se okrenuo identifikaciji kroz objekte, nameštaj, automobile, odeću itd.

Nakon Drugog svetskog rata globalizacija i već razvijeno konzumersko društvo dovelo je do identifikacije čoveka isključivo kroz znakove koji stoje ispred tih objekata. Do ovog trenutka arhitekte su mogle da se bave korisnikovim načinima identifikacije ali šta se dešava kada ta identifikacija postane 2D slika, koja je tu uloga arhitekte? Nije puka slučajnost što danas ljudi koji pišu kodove i stvaraju virtuelni svet nose titulu upravo arhitekte?

Mišel Uelbek je u svom eseju "Građenje polica" [3], analizirajući današnje konzumersko društvo izjavio da će korisnici srušene zidove u stanovima zameniti mobilnim pregradama u vidu polica koje će se retko pomerati a njihova suština je da napravi dodatni osećaj slobode kod čoveka.
Beli zidovi i proziran nameštaj stvoriće neutralni prostor kroz koji će se reklamne poruke slobodno širiti.

Kako smo daleko od toga da digitalni prostori $\mathrm{u}$ potpunosti zamene fizičke, ne može a da se nepostavi pitanje uloge arhitekte u današnjem svetu i u budućnosti.

Da bi se arhitekta odn. dizajner kvalitetno bavio prostorom neophodno je da razume nove potrebe korisnika, nove navike i psihološke okvire nastale preklapanjem ovih multiprostora (fizičkog i digitalnih).

\section{LITERATURA}

[1] https://www.ecologicstudio.com/projects/photo-synthetica

[2] Jean Baudrillard - System of Objects, 1968

[3] Mchel Uelbek - Building shelves, 1993

\section{Kratka biografija:}

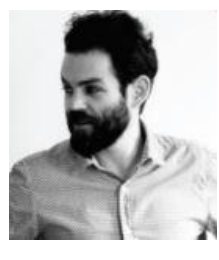

Aleksa Bugarski rođen je u Novom Sadu 1989. god. Master rad na Fakultetu tehničkih nauka iz oblasti Arhitektura Enterijer stambene jedinice - analiza uticaja tehnologije na dizajn odbranio je 2021.god.

kontakt: bugarski.aleksa89@gmail.com 